\title{
Fish community in a large coastal subtropical lake: how an environmental gradient may affect the structure of trophic guilds
}

\author{
Lúcia Ribeiro Rodrigues ${ }^{1, *}$, David da Motta Marques $^{1}$ and Nelson Ferreira Fontoura ${ }^{2}$ \\ ${ }^{1}$ Laboratório de Ecotecnologia e Limnologia, Instituto de Pesquisas Hidráulicas, Universidade Federal do Rio \\ Grande do Sul, Av. Bento Gonçalves 9500, 91.501-970, Porto Alegre, RS, Brazil. \\ ${ }^{2}$ Laboratório de Ecologia Aquática, Faculdade de Biociências, Pontifícia Universidade Católica do Rio Grande \\ do Sul, Av. Ipiranga 6681, 90.619-900, Porto Alegre, RS, Brazil.
}

* Corresponding author: luciarrodrigues@gmail.com

Received: 20/10/14 Accepted: 12/2/15

\begin{abstract}
Fish community in a large coastal subtropical lake: how an environmental gradient may affect the structure of trophic guilds

Biological communities change in time and space under driving pressures from differences in habitat structure, resource availability, interspecific competition, predation and other factors. Spatial heterogeneity, or patchiness, has been recognized as an important feature in a number of lake systems. In this study, we analysed changes in the seasonal dynamics of fish community in a subtropical lake over one year, focusing on the spatial and temporal distribution of fish biomass and species composition. Mangueira is a large shallow lake ( $3 \mathrm{~m}$ deep in average, $90 \mathrm{~km}$ long, $3-10 \mathrm{~km}$ wide, $\approx 820 \mathrm{~km}^{2}$ ) located along the Atlantic coast-line in southern Brazil $\left(33^{\circ} 31^{\prime} 22^{\prime \prime} \mathrm{S} 53^{\circ} 07^{\prime} 48^{\prime \prime} \mathrm{W}\right)$. Mangueira Lake presents longitudinal gradients in both biotic and abiotic factors, and a principal components analysis (PCA) showed temporal and spatial gradients in the system. Analysis of similarity (ANOSIM) showed significant differences between the north and south extremes of Mangueira Lake. Secchi transparency $(p<0.001)$, dissolved organic carbon (DOC) $(p=0.03)$ and chlorophyll $a(p<0.001)$ were identified as the driving factors for this spatial gradient. A two-way ANOVA was adjusted for each data set. Chlorophyll $a(p=0.017)$, fish captures $(p=0.033)$ and fish richness $(p=0.026)$ were different according to the sampling site (after removing the seasonal effect), while only fish richness presented significant seasonal variation after removing the sampling site effect $(p=0.041)$. This longitudinal gradient can be related to two main driving pressures. The first is prevailing winds from northeast to southwest, with predictable consequences for the whole trophic cascade. The other structuring pressure is the interface of the Taim wetland with northern Mangueira Lake. Thus, the northern part presents more turbid water, muddy sediments and increased chlorophyll $a$ concentration, while the southern part is characterized by increased water transparency, less chlorophyll $a$ concentration and more PVI (percent volume infested) of submerged macrophytes, demonstrating the spatial heterogeneity of the ecosystem.
\end{abstract}

Key words: Shallow lake, spatial gradient.

\section{RESUMO}

Comunidade de peixes em uma grande lagoa costeira subtropical: como um gradiente ambiental pode afetar a estrutura das guildas tróficas

Comunidades biológicas mudam no tempo e no espaço, pressionadas por diferenças na estrutura do habitat, disponibilidade de recursos, competição interespecífica e predação, dentre e outros fatores. A heterogeneidade espacial, ou patchiness, tem sido reconhecida como um fator importante de estruturação em uma série de sistemas lacustres. Neste estudo, foram analisadas mudanças na dinâmica sazonal da comunidade de peixes de uma lagoa subtropical ao longo de um ano, com foco na distribuição espacial e temporal da biomassa de peixes, assim como na composição de espécies. A lagoa Mangueira $(3 \mathrm{~m}$ de profundidade, em média, $90 \mathrm{~km}$ de comprimento, $3-10 \mathrm{~km}$ de largura, $\approx 820 \mathrm{~km}^{2}$ ), encontra-se disposta ao longo da costa do Atlântico, no sul do Brasil ( $\left.33^{\circ} 31^{\prime} 22^{\prime \prime} S 53^{\circ} 07^{\prime} 48^{\prime \prime} \mathrm{W}\right)$, apresentando gradientes longitudinais em fatores bióticos e abióticos. Através de análise de componentes principais (PCA), gradientes espaciais e temporais no sistema foram identificados. Análise de similaridade (ANOSIM) evidenciou diferenças significativas entre os extremos norte e sul da lagoa. Transparência Secchi 
( $\mathrm{p}<0.001)$, carbono orgânico dissolvido $(D O C)(\mathrm{p}=0.03)$, e clorofila a $(\mathrm{p}<0.001)$, foram identificados como os fatores determinantes para este gradiente espacial. Uma ANOVA de duas vias foi ajustada para cada conjunto de dados. Clorofila a $(\mathrm{p}=0.017)$, capturas de peixe $(\mathrm{p}=0.033)$ e riqueza de peixes $(\mathrm{p}=0.026)$ foram diferentes de acordo com o local de amostragem (após extraído o efeito de sazonalidade), enquanto apenas riqueza de peixe apresentou variação sazonal significativa após a remoção do efeito do local de amostragem $(\mathrm{p}=0.041)$. Este gradiente longitudinal pode ser relacionado a dois principais forçantes. O primeiro está relacionado aos ventos dominantes de nordeste para sudoeste, com consequências em toda a cascata trófica. A outra pressão estruturante relaciona-se com a interface com o banhado do Taim, no norte da lagoa Mangueira. Assim, a parte norte apresenta água mais turva, sedimentos lodosos e aumento da concentração de clorofila a, enquanto a parte sul é caracterizada pelo aumento da transparência da água, menor concentração de clorofila a e maiores valores de PVI (cobertura percentual) de macrófitas submersas, demonstrando a heterogeneidade espacial do ecossistema.

Palavras chave: Lago raso, gradiente espacial.

\section{INTRODUCTION}

Biological communities change in time and space as result of habitat structure, resource availability (Grenouillet et al., 2002), interspecific competition (Harrison \& Hildrew, 2001), predation (Zerba \& Collins, 1992) and other factors. In particular, fish play a key role in the trophic dynamics of lakes, not least in shallow systems. Through predation on zooplankton, planktivorous fish may promote cascading trophic effects, leading to increased phytoplankton biomass and reduced water transparency (Carpenter \& Kitchell, 1993). Fish also link littoral, benthic and pelagic zones through nutrient translocation and biotic interactions across habitats (Vander Zanden \& Vadeboncoeur, 2002).

Recognition of the importance of spatial and temporal scales is a relatively recent issue in ecological research on aquatic systems (Woodward \& Hildrew, 2002; Bell et al., 2003, Mehner et al., 2005). Spatial heterogeneity has been recognized as an important feature in a number of lake systems for a wide range of environmental variables and organisms (Pinel-Alloul et al., 1999, Thackeray et al., 2004); it results from a combination of organisms' behavioural responses (e.g., feedback between water chemistry and organisms, predator-prey interactions), physical processes (e.g., wind-induced turbulence, internal seiches) (Cardoso et al., 2012) and presence of aquatic macrophytes (Meerhoff et al., 2007; Teixeira-de-Mello et al., 2009).

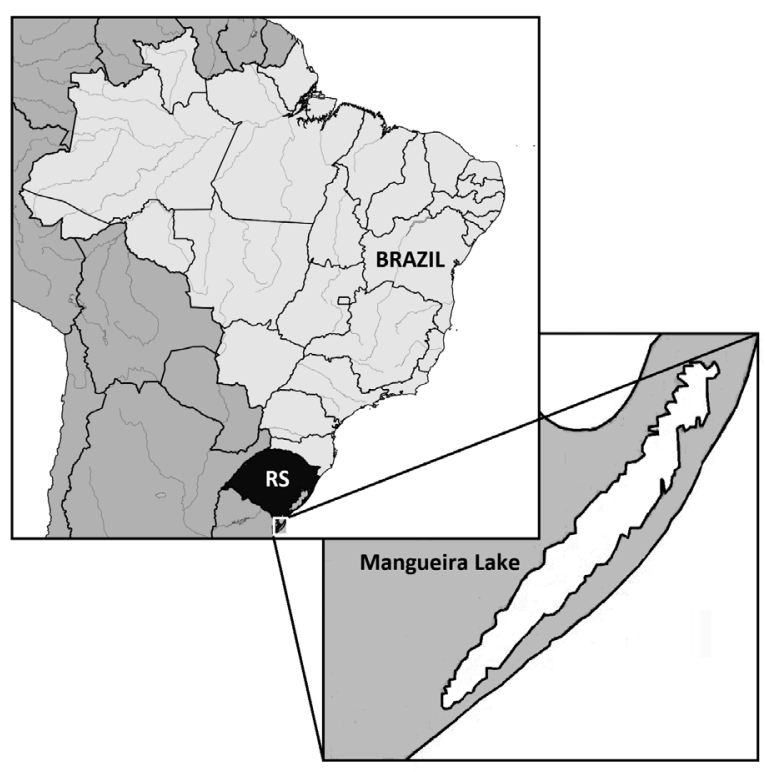

Figure 1. Mangueira Lake, coastal lake in Rio Grande do Sul State (RS), southern Brazil. Lagoa Mangueira, lagoa costeira do Rio Grande do Sul (RS), sul do Brasil.

In large shallow lakes, where wind-induced water movements have a dominant effect on distribution patterns, wind can be a dominant factor leading to both spatial and temporal heterogeneity (Thackeray et al., 2004; Cardoso \& Motta Marques, 2009; Cardoso et al., 2012). Water movement in aquatic systems is a key factor that drives resource distribution, suspends and carries particles, reshapes the physical habitat and makes available previously unavailable resources. Following such processes, communi- 
ties change and patterns are created in time and space (Cardoso et al., 2012).

Several studies have focused on the structure of shallow lake communities in temperate areas (Carpenter \& Lodge, 1986; Moss, 1990; Jeppesen et al., 1997; Teixeira-de-Mello et al., 2009), although a tropical and subtropical ecosystem may present greater complexity both in structure and trophic interactions (Lazzaro, 1997; Teixeira-de-Mello et al., 2009). In the present study, we analysed patterns of change in both spatial and seasonal dynamics concerning chemical and physical water characteristics in Mangueira Lake, southern Brazil. We also investigated the distribution and abundance of fish in the littoral zones (north and south) of Mangueira Lake. Due to a remarkable elongated shape aligned with prevailing winds, this lake provides an ideal model system to investigate spatial heterogeneity in relation to a longitudinal gradient of both biotic and abiotic factors.

\section{METHODS}

\section{Study site}

Mangueira is a large shallow lake ( $3 \mathrm{~m}$ deep in average, $90 \mathrm{~km}$ long, 3-10 km wide, $\sim 820 \mathrm{~km}^{2}$ ) located along the Atlantic coast-line in southern Brazil ( $\left.33^{\circ} 31^{\prime} 22^{\prime \prime} \mathrm{S} 53^{\circ} 07^{\prime} 48^{\prime \prime} \mathrm{W}\right)$ (Fig. 1). The lake was formed after the last post-glacial marine regression (Holocene, $\sim 5000 \mathrm{BP}$ ), when the ocean level fell five metres to the present level (Tomazelli et al., 2000). Its regional climate is subtropical, with a mean annual temperature of $16^{\circ} \mathrm{C}$ and precipitation between 1800 and $2200 \mathrm{~mm}$ (Cfa type; Kottek et al., 2006), and the trophic state ranges from oligotrophic to mesotrophic (Crossetti et al., 2013). The lake is oriented according to the prevailing wind direction (NE-SW). At its southern and northern boundaries, the lake interfaces with wetlands. In the south, large areas are present with submerged, free floating and emergent macrophytes; in the north, there is a large area with free floating and emergent macrophytes, forming the Taim Hydrological System (THS), which is a federal conservation unit.

\section{Sampling and field measurements}

Limnological and biological data were collected at two sampling points in the littoral zone of Mangueira Lake: north (N; 32.770 S 52.579 W) and south $(\mathrm{S} ; 33.510 \mathrm{~S} 53.126 \mathrm{~W})$, both in its interface with wetlands. The samplings were performed seasonally, from the winter of 2006 to the autumn of 2007 (in August, November, February and May).

Water temperature, dissolved oxygen and $\mathrm{pH}$ were measured with a multiparameter probe (YSI 6600). Transparency was estimated with a Secchi disk and depth with a handheld sonar system. Water samples for chemical analysis were collected using a water column sampler, extracting samples of the entire water column from the surface to a depth of two metres. After homogenizing, a sub-sample was stored and conserved following the recommended protocols (APHA, 1999).

Fish were sampled using multi-mesh gillnets $(5,6.25,8,10,12.5,15,20,25,30,35,40$, $45,50,55,60,65$, and $70 \mathrm{~mm}$ ), the length and depth of each mesh section being 3 and $1.5 \mathrm{~m}$, respectively. Nets were set in triplicate in the late afternoon and retrieved the following morning. Data represent the average catch among nets, expressed as catch per unit effort (CPUE; $\mathrm{Kg} \cdot$ net $^{-1} \cdot 16 \mathrm{~h}$ ), and all captured fish were euthanized in a water solution containing $285 \mu \mathrm{g} / \mathrm{L}$ eugenol and then preserved in $4 \%$ formalin.

\section{Sample and data analysis}

Total phosphorus (TP) and total nitrogen (TN) were determined using colorimetric methods following Mackereth et al. (1989). Total solids (TS) were determined gravimetrically following APHA (1999), and carbon analysis -dissolved organic (DOC) and dissolved inorganic (DIC)was determined via a carbon analyser (Shimadzu $\mathrm{V} c \mathrm{ph}$ 5000). Chlorophyll $a$ was quantified after cold ethanol extraction (Jespersen \& Christoffersen, 1987) and measured by the spectrophotometric method (APHA, 1999).

In the laboratory, fish were identified to the species level, measured (total length, to nearest 
$\mathrm{mm}$ ) and weighed with a semi-analytical balance (to nearest $0.01 \mathrm{~g}$ ). The fish species were grouped according to feeding habits (functional guilds) after stomach content analysis. Each species was assigned to one of the following feeding guilds: mainly invertebrate (MI), mainly fish (MF), detritus (D), invertebrates and fish (IF), planktivorous and invertebrates (PI) and omnivorous (OV), adapted from Sánchez-Botero et al. (2008).

\section{Statistical Analysis}

Ordination analysis was performed using the software PC-ORD version 4.0 for Windows (McCune \& Mefford, 1999). Principal components analysis (PCA) was undertaken to determine spatial and temporal changes of physical and chemical conditions, and the abiotic data were transformed by $\log x+1$. Analysis of similarity (ANOSIM) was applied to identify dissimilarity between environmental variables and attributes of the fish community in the north and south. Bonferroni correction was applied to the analysis of Bray-Curtis similarity through PAST statistical software version 1.72 (Hammer et al., 2001). An ANOVA (two-way) test was used to evaluate the effect of seasons and sampling site on attributes of the fish community in Mangueira Lake.

\section{RESULTS}

\section{Limnological scenario}

Our results showed considerable spatial (northsouth) and temporal (seasonal) variation in limnological variables in Mangueira Lake (Table 1). Nutrient dynamics, mainly for total nitrogen (TN) and total phosphorus (TP), were driven by seasonality. Total nitrogen and total phosphorus were generally low in both sampling sites but with increased concentrations in the summer (Table 1). Total nitrogen ranged from $0.276 \mathrm{mg} / \mathrm{L}$ to $1.650 \mathrm{mg} / \mathrm{L}$ in the south and from $0.285 \mathrm{mg} / \mathrm{L}$ to $1.515 \mathrm{mg} / \mathrm{L}$ in the north, while total phosphorus ranged from $0.019 \mathrm{mg} / \mathrm{L}$ to $0.099 \mathrm{mg} / \mathrm{L}$ in the south and from $0.030 \mathrm{mg} / \mathrm{L}$ to $0.071 \mathrm{mg} / \mathrm{L}$ in the north. DOC presented lower values in the north $(16.13 \pm 3.40 \mathrm{mg} / \mathrm{L})$ compared with the south $(20.13 \pm 2.75 \mathrm{mg} / \mathrm{L})$. Secchi transparency showed the highest values in the southern sampling site (average $=1.15 \mathrm{~m}$ ) compared with the north (average $=0.45 \mathrm{~m}$ ). Notable differences in chlorophyll $a$ concentration were found between the north (average $=9.5 \mu \mathrm{g} / \mathrm{L})$ and the south (average $=2.7 \mu \mathrm{g} / \mathrm{L})($ Table 1$)$.

Analysis of similarity (ANOSIM) applied to environmental variables showed significant differences between the sampling sites (north and

Table 1. Limnological variables measured in Mangueira Lake, southern Brazil. Variáveis limnológicas medidas na lagoa Mangueira, Sul do Brasil.

\begin{tabular}{|c|c|c|c|c|c|c|c|c|}
\hline \multirow{2}{*}{ Limnological variable } & \multicolumn{2}{|c|}{ Winter } & \multicolumn{2}{|c|}{ Spring } & \multicolumn{2}{|c|}{ Summer } & \multicolumn{2}{|c|}{ Autumn } \\
\hline & North & South & North & South & North & South & North & South \\
\hline Water temperature $\left({ }^{\circ} \mathrm{C}\right)$ & 14.8 & 13.5 & 17.0 & 16.0 & 26.0 & 24.8 & 12.7 & 12.4 \\
\hline Dissolved Oxygen (mg/L) & 10.3 & 11.9 & 9.9 & 9.8 & 9.9 & 8.6 & 9.1 & 8.6 \\
\hline $\mathrm{pH}$ & 8.1 & 8.1 & 7.9 & 7.8 & 7.6 & 7.3 & 7.9 & 7.6 \\
\hline Depth (m) & 1.7 & 2.0 & 1.8 & 2.1 & 1.3 & 1.6 & 1.0 & 1.6 \\
\hline Secchi transparency (m) & 0.7 & 2.0 & 0.2 & 1.0 & 0.4 & 0.8 & 0.5 & 0.8 \\
\hline Total Solids (mg/L) & 391 & 162 & 314 & 189 & 440 & 366 & 141 & 112 \\
\hline $\mathrm{DOC}(\mathrm{mg} / \mathrm{L})$ & 20.5 & 17.5 & 17.1 & 24.0 & 14.5 & 19.5 & 12.5 & 19.5 \\
\hline DIC (mg/L) & 23.8 & 17.4 & 27.5 & 24.7 & 27.4 & 16.3 & 19.0 & 13.5 \\
\hline $\mathrm{TP}(\mathrm{mg} / . \mathrm{L})$ & 0.044 & 0.019 & 0.071 & 0.034 & 0.051 & 0.099 & 0.030 & 0.039 \\
\hline TN (mg/L) & 0.443 & 0.276 & 0.911 & 0.922 & 1.515 & 1.650 & 0.285 & 0.303 \\
\hline Chlorophyll $a(\mu \mathrm{g} / \mathrm{L})$ & 7.2 & 4.0 & 10.9 & 1.6 & 11.5 & 3.0 & 8.4 & 2.3 \\
\hline
\end{tabular}

North and South = sampling sites; TP, Total Phosphorus; TN, Total Nitrogen; DOC, Dissolved Organic Carbon; DIC, Dissolved Inorganic Carbon. 


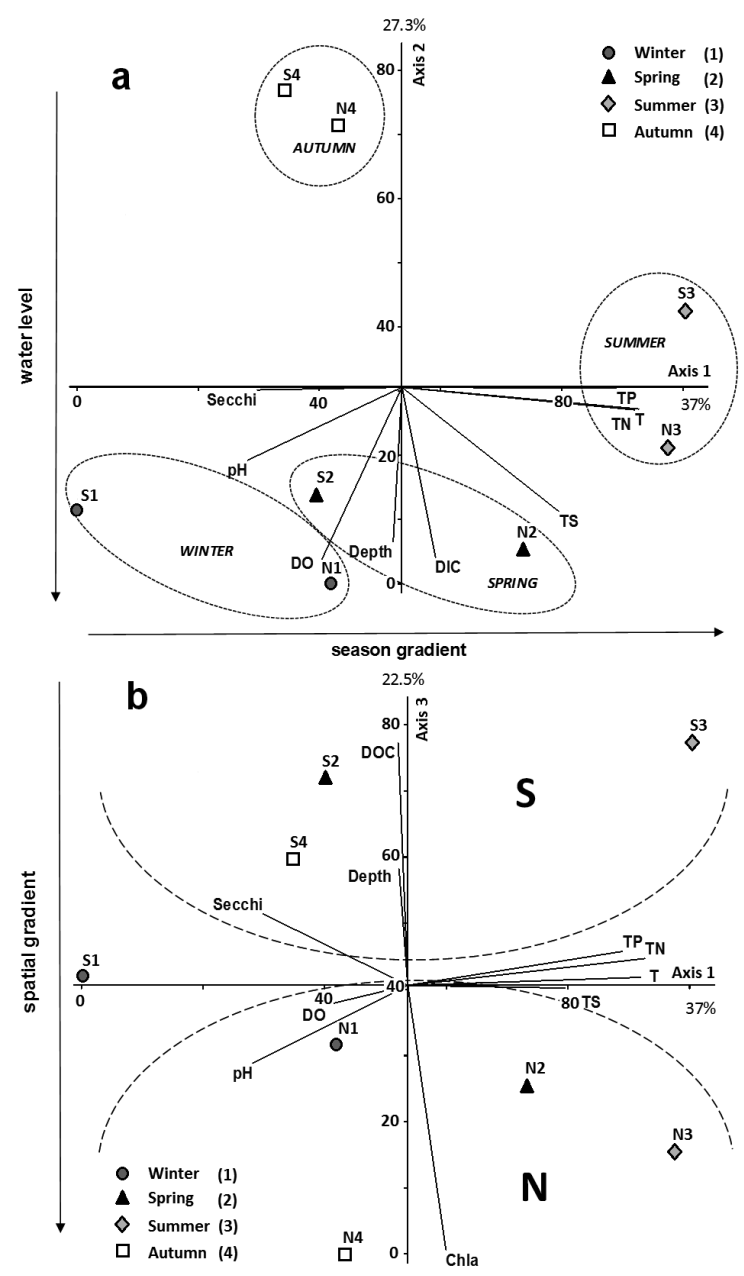

Figure 2. Scores derived from the principal components analysis (PCA) applied to environmental variables in Mangueira Lake: axis 1 and 2 (a); axis 1 and 3 (b). Sampling site = North $(\mathrm{N})$ and South $(\mathrm{S})$; $\mathrm{T}=$ water temperature; TP = total phosphorus; $\mathrm{TN}=$ total nitrogen; $\mathrm{TS}=$ total solids; $\mathrm{DOC}=$ dissolved organic carbon; DIC = dissolved inorganic carbon; DO = dissolved oxygen; Chla $=$ chlorophyll $a$. Escores da análise de componentes principais (PCA) aplicada às variáveis ambientais na lagoa Mangueira: eixo 1 e 2 (a); eixos 1 e 3 (b). Local de amostragem $=$ Norte $(N)$ e Sul $(S) ; T=$ temperatura da água; $T P=$ fósforo total $; T N=$ nitrogênio total $; T S=$ sólidos totais; $D O C=$ carbono orgânico dissolvido $;$ DIC $=$ carbono inorgânico dissolvido; $\mathrm{DO}=$ oxigênio dissolvido; Chla $=$ clorofila a.

South). Secchi transparency $(R=0.43, p<0.001)$, DOC $(R=0.22, p=0.03)$ and chlorophyll $a$ $(R=0.67, p<0.001)$ were significantly different between the sampling sites.

The principal components analysis (PCA) assessed the main trends among limnological variables in Mangueira Lake, showing temporal (Fig. 2a; PCA axis 1 and 2) and spatial (Fig. 2b; PCA axis 1 and 3) gradients. By using 11 abiotic variables, the PCA explained $84.9 \%$ of data variability in the first three axes (axis $1=37 \%$; axis $2=27.3 \%$; axis $3=22.5 \%$ ). The most important variables for axis 1 ordination were temperature (0.87), Secchi (-0.69), TS (0.70), $\mathrm{TP}(0.82)$, TN (0.87) and $\mathrm{pH}(-0.76)$. Axis 2 was related mainly to DO $(-0.70)$, DIC $(0.69)$ and depth (-0.71), whereas for axis 3, chlorophyll $a$ $(0.84)$ and DOC $(-0.80)$ were the more relevant parameters. Axis 1 showed a temporal gradient, axis 2 was related to depth, reflecting the lake water level, and axis 3 clearly separates north and south samples, indicating a spatial gradient.

\section{Biotic data}

The fish checklist resulted in 36 species, distributed in 6 orders (Table 2). The captures were a small proportion of total fish population and were irrelevant to population sustainability. Richness comprised 32 fish species in the northern sampling site, whereas 29 fish species were captured in the south. A total of 3479 fish specimens were collected, with 2496 in the northern and 983 in the southern extremes of Mangueira Lake. Fish biomass also reflected this north/south pattern, with an overall $130 \mathrm{~kg}$ captured in the northern sampling site, whereas only $45 \mathrm{~kg}$ were captured in the southern sampling site. These identified differences were confirmed by analysis of similarity (ANOSIM): total biomass, $R=0.17, p=0.01$; number of captures, $R=0.47, \quad p<0.001$; and species richness, $R=0.21, p=0.01$.

Characiformes was the most represented order by number of captured specimens and biomass. Oligosarcus jenynsii was the most abundant species both as total capture frequency (28\%) and biomass (26\%) in northern Mangueira Lake. Cyphocharax voga, although having low frequency $(8 \%)$, represented $23 \%$ of captured biomass in the northern site. In southern Mangueira Lake, Bryconamericus iheringii was the most represented species captured (29\%) but had low biomass ( $2 \%$ ), while Hoplias mala- 
Table 2. Captured fish species, functional guild classifications (mainly invertebrate: MI; mainly fish: MF; detritus: D; invertebrates and fish: IF; planktivorous and invertebrates PI; and omnivorous: OV) and captured fish biomass in north and south Mangueira Lake, southern Brazil. Espécies de peixes capturadas e enquadramento em guildas funcionais (dominância de invertebrados: MI, dominância de peixes: MF; detritos: D; invertebrados e peixes: IF; plâncton e invertebrados: PI; e onívoros: OV) e biomassa de peixes capturados no norte e sul lagoa Mangueira, sul do Brasil.

\begin{tabular}{|c|c|c|c|c|c|}
\hline \multirow[t]{2}{*}{ Order/Species } & \multirow{2}{*}{ Feeding Guild } & \multicolumn{2}{|c|}{ Captures $(\%)$} & \multicolumn{2}{|c|}{ Biomass $(\%)$} \\
\hline & & North & South & North & South \\
\hline \multicolumn{6}{|l|}{ Clupeiformes } \\
\hline Platanichthys platana (Regan, 1917) & PI & 10.98 & 3.66 & 0.34 & 0.17 \\
\hline \multicolumn{6}{|l|}{ Characiformes } \\
\hline Cyphocharax voga (Hensel, 1870) & $\mathrm{D}$ & 7.93 & 12.00 & 23.27 & 13.62 \\
\hline Hoplias malabaricus (Bloch, 1794) & MF & 0.64 & 2.54 & 5.84 & 20.73 \\
\hline Astyanax eigenmanniorum (Cope, 1894) & OV & 5.33 & 7.12 & 0.72 & 1.47 \\
\hline A. fasciatus (Cuvier, 1819) & OV & 0.00 & 1.02 & 0.00 & 0.11 \\
\hline A. jacuhiensis (Cope, 1894) & OV & 4.05 & 2.95 & 0.74 & 0.53 \\
\hline Astyanax sp. & $\mathrm{OV}$ & 7.25 & 5.29 & 0.77 & 0.54 \\
\hline Bryconamericus iheringii (Boulenger, 1887) & PI & 7.45 & 29.20 & 0.55 & 2.38 \\
\hline Charax stenopterus (Cope, 1894) & - & 0.16 & 1.83 & 0.03 & 0.24 \\
\hline Cheirodon ibicuhiensis Eigenmann, 1915 & - & 0.04 & 0.00 & 0.00 & 0.00 \\
\hline Cheirodon interruptus (Jenyns, 1842) & & 0.36 & 0.00 & 0.03 & 0.00 \\
\hline Cyanocharax alburnus (Hensel, 1870) & PI & 10.74 & 3.36 & 0.31 & 0.17 \\
\hline Hyphessobrycon bifasciatus Ellis, 1911 & - & 0.00 & 0.41 & 0.00 & 0.04 \\
\hline H. luetkenii (Boulenger, 1887) & OV & 3.17 & 7.32 & 0.23 & 0.56 \\
\hline Oligosarcus jenynsii (Günther, 1864) & MI & 28.04 & 14.24 & 25.75 & 17.88 \\
\hline O. robustus Menezes, 1969 & MF & 1.48 & 0.41 & 4.57 & 0.67 \\
\hline \multicolumn{6}{|l|}{ Siluriformes } \\
\hline Trachelyopterus lucenai Bertoletti, Silva \& Pereira, 1995 & OV & 0.60 & 0.92 & 2.16 & 2.46 \\
\hline Pimelodella australis Eigenmann, 1917 & - & 0.56 & 0.10 & 0.08 & 0.04 \\
\hline Rhamdia quelen (Quoy \& Gaimard, 1824) & OV & 0.84 & 0.81 & 14.47 & 11.14 \\
\hline Corydoras paleatus (Jenyns, 1842) & - & 0.24 & 0.00 & 0.02 & 0.00 \\
\hline Hoplosternum littorale (Hancock, 1828) & - & 0.04 & 0.00 & 0.22 & 0.00 \\
\hline Hisonotus taimensis (Buckup, 1981) & - & 0.20 & 0.10 & 0.01 & 0.00 \\
\hline Hypostomus commersoni Valenciennes, 1836 & - & 0.12 & 0.00 & 1.69 & 0.00 \\
\hline Loricariichthys anus (Valenciennes, 1836) & - & 0.56 & 0.00 & 3.79 & 0.00 \\
\hline Rineloricaria longicauda Reis, 1983 & - & 0.48 & 0.20 & 0.06 & 0.02 \\
\hline \multicolumn{6}{|l|}{ Cyprinodontiformes } \\
\hline Jenynsia multidentata (Jenyns, 1842) & - & 0.04 & 0.00 & 0.00 & 0.00 \\
\hline \multicolumn{6}{|l|}{ Atheriniformes } \\
\hline Odontesthes bonariensis (Valenciennes, 1835) & MI & 0.04 & 0.00 & 0.24 & 0.00 \\
\hline O. humensis de Buen, 1953 & MI & 1.28 & 3.26 & 5.99 & 17.81 \\
\hline O. mirinensis Bemvenuti, 1995 & MI & 5.49 & 0.71 & 3.82 & 0.45 \\
\hline O. perugiae Evermann \& Kendall, 1906 & MI & 0.56 & 0.00 & 1.05 & 0.00 \\
\hline O. retropinnis (de Buen, 1953) & MI & 0.96 & 0.41 & 2.65 & 1.79 \\
\hline \multicolumn{6}{|l|}{ Perciformes } \\
\hline Crenicichla lepidota Heckel, 1840 & MF & 0.04 & 0.51 & 0.05 & 0.46 \\
\hline C. punctata Hensel, 1870 & MF & 0.00 & 0.20 & 0.00 & 0.04 \\
\hline Gymnogeophagus gymnogenys (Hensel, 1870) & - & 0.16 & 0.71 & 0.18 & 0.41 \\
\hline G. rhabdotus (Hensel, 1870) & - & 0.12 & 0.00 & 0.07 & 0.00 \\
\hline Geophagus brasiliensis (Quoy \& Gaimard, 1824) & OV & 0.04 & 0.71 & 0.27 & 6.25 \\
\hline
\end{tabular}




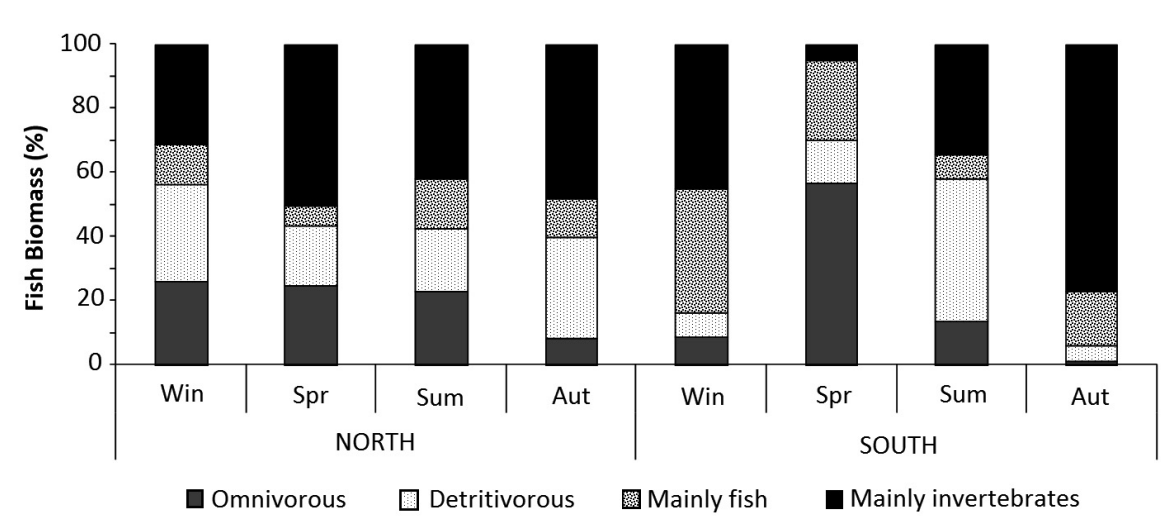

Figure 3. Fish biomass by feeding guild in Mangueira Lake during the study. Biomassa de peixes por guilda trófica na lagoa Mangueira durante o estudo.

Table 3. Fish abundance and richness in relation to seasonal and spatial drivers in north and south sampling sites in Mangueira Lake, southern Brazil. Abundância de peixes e riqueza específica em função de forçantes sazonais e espaciais nos locais de amostragem ao norte e ao sul da lagoa Mangueira, sul do Brasil.

\begin{tabular}{|c|c|c|c|c|c|c|}
\hline & \multicolumn{2}{|c|}{ Biomass (g.net-1) } & \multicolumn{2}{|c|}{ Captures (individuals) } & \multicolumn{2}{|c|}{ Richness (species) } \\
\hline & South & North & South & North & South & North \\
\hline Winter & 7506 & 30989 & 68 & 307 & 12 & 17 \\
\hline Spring & 6065 & 7375 & 302 & 357 & 15 & 19 \\
\hline Summer & 4714 & 12792 & 70 & 246 & 13 & 20 \\
\hline Autumn & 4346 & 13699 & 52 & 340 & 8 & 10 \\
\hline
\end{tabular}

baricus was the most represented species as biomass $(21 \%)$, followed by $O$. jenynsii $(18 \%)$ and Odontesthes humensis (18\%).

The values for fish biomass, number of captured individuals and species richness can be observed in Table 3 for each sampling site and season. A two-way ANOVA (Table 4) was adjusted for each data set (Table 1: Chlorophyll $a$; Table 2: fish biomass, captures and richness). Chlorophyll $a(p=0.017)$, fish captures $(p=0.033)$ and fish richness $(p=0.026)$ were different by sampling site (after removing the seasonal effect), while only fish richness presented a significant seasonal variation after removing the sampling site effect $(p=0.041)$.

The more frequent fish species were classified as functional feeding guilds (Table 2). Figure 3 presents guild distribution by sampling site and season. High percentages of the mainly invertebrate eaters $(38 \%)$, detritivorous $(28 \%)$ and omnivorous $(21 \%)$ guilds were present in the northern site, while mainly fish eaters were less frequent $(13 \%)$. In southern Mangueira Lake, the trophic structure is similar, but with an inversion. An increased presence of mainly fish eaters $(25 \%)$ and a decrease of detritivorous fish $(16 \%)$ were identified, although mainly invertebrate eaters $(41 \%)$ and omnivorous fish $(19 \%)$ were present in similar frequencies. The planktivorous guild was not important as captured biomass in either site, although $B$. iheringii was a dominant species in number of captures in southern Mangueira Lake.

\section{DISCUSSION}

The results showed the heterogeneity of the ecosystem with marked spatial (northern-southern) and temporal (seasonal) differences in both biotic and abiotic factors in Mangueira Lake, as was already observed by Crossetti et al. 
Table 4. Significance values from two way ANOVA analysing seasonal and spatial drivers in relation to fish abundance and richness and chlorophyll $a$ concentration in Mangueira Lake during the study period. Interaction measurements are not available because there were no repetitions in any data category. Data are from Table 1 and 2. Valores de significância (ANOVA de duas vias) de forçantes sazonais e espaciais em relação à abundância de peixes, riqueza específica e concentração de clorofila a na lagoa Mangueira durante o período do estudo. Medidas de interação não estão disponíveis pela falta de repetições em cada categoria de dados. Os dados originais encontram-se nas Tabelas 1 e 2.

\begin{tabular}{lcc}
\hline & Seasons effect & Sampling site effect \\
\hline Chlorophyll $a$ & 0.767 & $\mathbf{0 . 0 1 7}$ \\
Fish Captures & 0.257 & $\mathbf{0 . 0 3 3}$ \\
Fish Biomass & 0.381 & 0.108 \\
Fish Richness & $\mathbf{0 . 0 4 1}$ & $\mathbf{0 . 0 2 6}$ \\
\hline
\end{tabular}

(2013) for phytoplankton functional groups. Spatial heterogeneity is a common feature of ecosystems and is the product of many interacting drivers governing biological and physical processes (Thackeray et al., 2004). In this regard, large shallow lakes provide suitable conditions for the development of spatial heterogeneity, especially considering hydrodynamic features that might result from strong wind influence (Cardoso \& Motta-Marques, 2009; Hennemann \& Petrucio, 2011).

The availability of nutrients has an essential role in the primary production and function of lake ecosystems. The loading and cycling of nitrogen and phosphorus can determine many features of aquatic systems (Reynolds, 2006). A consensus has emerged that nutrients are key factors in shallow systems, but the extent to which their potential influence may be realized is very much a function of the food-web structure and how it can be modified by nutrient loading.

In this regard, Mangueira Lake could be viewed as an almost closed system, as there are no significant water contributions from watersheds, except from some small streams in its western boundary. Considering the large area of nearby rice fields, surface water balance could be considered negative, with more water pumped out during spring and summer than reaches the system by stream contribution. Although it has low riverine contribution to both northern and southern extremes, Mangueira Lake is connected with wetlands. The southern wetland $\left( \pm 12 \mathrm{~km}^{2}\right)$ has no external connection, except an artificial channel for water pumping to rice fields. On the other hand, the northern wetland, comprising the Taim Hydrological System, presents approximately $200 \mathrm{~km}^{2}$ of interconnected wetlands, merging directly with Mirim Lagoon (total surface area of $3749 \mathrm{~km}^{2}$ ) via wetlands and small channels. In this regard, especially during the spring and summer, the water pumped out to supply rice farming can be replaced (or partially replaced) by water inflow from Mirim Lagoon. In this regard, Mangueira Lake functions as an almost closed system during the autumn and winter (with no rice farming) and an open system during the spring and summer (with water pumped out for irrigation and inflow from Mirim Lagoon).

The most important differences in limnological properties between the extremities of Mangueira Lake are in water transparency, DOC, chlorophyll $a$ concentration and fish abundance. The southern sampling site was characterized by increased water transparency, less chlorophyll $a$ concentration and more PVI (percent volume infested) of submerged macrophytes, which, according to Finkler-Ferreira (2009), may be inhibiting phytoplankton and producing more DOC, except in the winter, when DOC values were larger in the northern site for unknown reasons. On the other hand, in the northern sampling site, there were increased chlorophyll $a$ concentration, lower water transparency, an absence of submerged macrophytes, and increased total solids, possibly due to the input of nutrients and organic matter from the Taim wetland, delineating a clear spatial gradient. In this regard, the wind direction could be a key factor to promote water interchange with the northern wetlands. When the wind is blowing from the south, water is piled up in the northern extreme of Mangueira Lake and invades the nearby Taim wetlands. After a change in the wind direction, usually to the northeast, the water flows back into Mangueira Lake, carrying organic matter and nutrients.

Large oligo-mesotrophic lakes may be expected to tend towards autotrophy because of low DOC values, long water renewal times and weaker coupling to terrestrial catchments (Boca- 
niov \& Smith, 2009). Autochthonous sources of DOC are related to phytoplankton, aquatic macrophytes and periphyton (Farjalla et al., 2004). This autochthonous primary production is responsible for a considerable part of the DOC in these aquatic environments (Wetzel, 1992). Southern Mangueira Lake presented a larger biomass of submerged, free floating and emergent macrophytes in all seasons (Finkler-Ferreira et al., 2008), constituting one of the hypotheses for the increased DOC concentration at this sampling site.

A temporal gradient related to nutrient dynamics was also found in the study. Seasonal differences are usually related to environmental factors, such as irradiance levels, temperature, and resource availability, especially nutrients and light (Wersal et al., 2006). Nevertheless, nutrient availability (TP and TN) is larger during the spring and summer; at the same time as rice culture is active. For this region, recommended fertilization is in the range of 10 to $90 \mathrm{~kg} / \mathrm{ha}$ for both phosphorus and nitrogen, depending on the soil properties, agricultural technique and seed type. This artificial nutrient input could be the key factor increasing $\mathrm{TP}$ and $\mathrm{TN}$ in spring-summer for both southern and northern Mangueira Lake. However, an interesting aspect should be mentioned. In northern Mangueira Lake, increased nutrient availability is followed by increased chlorophyll $a$ concentration, leading to direct resource availability for the entire food web, whereas this pattern was not observed in the southern sampling site. As already identified by Finkler-Ferreira (2009), submerged macrophytes are able to inhibit phytoplankton growth by means of allelopathic interaction. At the same time, as verified by Rodrigues et al. (2014) in their stable isotope analysis of the Mangueira food web, submerged macrophytes present too low carbon and nitrogen signatures in relation to primary consumers, and apparently are not directly important in sustaining the aquatic food web, possibly explaining the reduced fish abundance in southern Mangueira Lake.

The fish fauna of Mangueira Lake was dominated by Characiformes, as already described for South America by Lowe-McConnell (1987) and Agostinho \& Júlio Júnior (1999), but differences between the northern and southern sites were identified in the fish community structure.

Total fish biomass, number of captures and species richness presented high values in the northern sampling site, possibly due to increased habitat complexity derived from a huge lakewetland interface and greater phosphorus concentration, also indicated by chlorophyll $a$ values and biogenic turbidity.

A spatially structured community was also identified through the frequency distribution of different feeding guilds. Overall, mainly invertebrate eaters were the dominant feeding guild in both the northern and southern samples. North/south frequencies of omnivorous fish were quite similar in the $19-21 \%$ range, while planktivorous fish presented low captured biomass in both sites. However, it is interesting to note that the dominant main invertebrate eaters were different between the two sides of lake. In the northern sampling site, Oligosarcus jenynsii was the dominant invertebrate eater $(28 \%$ of the biomass), feeding mainly on crustaceans (Aegla sp. and Palaemonetes argentinus). In contrast, the dominant guild of invertebrate eaters in the southern sampling site was shared among Odontesthes humensis, consuming mainly mollusks (Heleobia sp. and Corbicula sp.) and Oligosarcus jenynsii, each representing $18 \%$ of the captured biomass. An inversion was also observed in the frequencies of detritivores and mainly fish eaters. Muddy sediments in the northern site may explain the high relative abundance of detritivores (28\%), whereas sandy sediments and clear waters could be related to the increased frequency of mainly fish eaters in the south, perhaps indicating easier prey detection. Relatedly, the dominant species in terms of biomass in the southern sampling site was H. malabaricus, a large carnivorous (manly piscivorous; MF) species, which comprised $21 \%$ of the captured biomass. Secchi transparency and maximum lake depth were similarly the most important factors structuring fish communities in floodplain lagoons of the Araguaia and Orinoco basins (Tejerina-Garro et al., 1998; Rodriguez \& Lewis Jr., 1997). This pattern was related to 
differential predation pressures from visually oriented piscivores in clear water and piscivores adapted for low light in turbid lagoons. However, it is important to identify that the northern sampling site presents a more stable community regarding feeding guilds, whereas the southern Mangueira Lake displays marked variation in trophic structure, presenting different dominance patterns in each sampling season. Reasons for this pattern are obscure, as local fish species are not known to migrate, and small-scale displacements, if present, are not described for most of the species. Nevertheless, the smaller captures in the southern site could also contribute to this increased temporal variability.

In summary, Mangueira Lake is a long shallow lake with a clear longitudinal gradient, both of biotic and abiotic factors. This longitudinal gradient can be related to two main driving pressures. The first structuring pressure is the Taim wetland interface with northern Mangueira Lake. Water flow from the wetlands carries both particulate material and nutrients to the northern site. The other pressure is prevailing winds from northeast to southwest (Fragoso Júnior. et al., 2008), which follow the lake's main axis, have a fetch that can reach $90 \mathrm{~km}$, and can move surface water through southern Mangueira Lake and provide energy to suspend fine sediments. At the same time, fine sediments and associated nutrients are transported to the north by bottom counter-currents, resulting in a southern sandy bottom, clear water, and lower chlorophyll $a$ concentration, with predictable consequences to the whole trophic cascade.

\section{ACKNOWLEDGMENTS}

We acknowledge the assistance provided by the National Institute of Environmental Protection (IBAMA, ESEC TAIM) and the National Council for Scientific and Technological Development (CNPq, Long Term Ecological Research Program) of Brazil, which fully supported this work (Grant No. 50027/1998-1). The manuscript was reviewed by Dr. Janet Reid (JWR Associates).

\section{REFERENCES}

AGOSTINHO, A. A. \& H. F. JÚLIO JÚNIOR. 1999. Peixes da bacia do alto rio Paraná. In: Estudos ecológicos de comunidades de peixes tropicais. $\mathrm{R}$. H. Lowe-McConnell (ed): 374-400. Edusp, São Paulo, Brazil.

AMERICAN PUBLIC HEALTH ASSOCIATION (APHA) 1999. Standard methods for the examination of water and wastewater. American Public Health Association, Washington DC, USA.

BELL, T., W. E. NEILL \& D. SCHLUTER. 2003. The effect of temporal scale on the outcome of trophic cascade experiments. Oecologia, 134: 578-586.

BOCANIOV, S. A. \& R. E. H. SMITH. 2009. Plankton metabolic balance at the margins of very large lakes: temporal variability and evidence for dominance of autochthonous processes. Freshwater Biology, 54: 345-362.

CARDOSO, L. S., C. R. FRAGOSO JÚNIOR., R. S. SOUZA \& D. M. MOTTA-MARQUES. 2012. Hydrodynamic control of plankton spatial and temporal heterogeneity in subtropical shallow lakes. In: Hydrodynamics: Natural Water Bodies. H.E. Schulz, A. L. A. Simoes \& R. J. Lobosco (Eds.): 27-48. Intech, Rijeka, Croatia.

CARDOSO, L. S. \& D. M. L. MOTTA-MARQUES. 2009. Hydrodynamics-driven plankton community in a shallow lake. Aquatic Ecology, 43: 73-84.

CARPENTER, S. R. \& D. M. LODGE. 1986. Effects of submerged macrophytes on ecosystem processes. Aquatic Botany, 26: 341-370.

CARPENTER, S. R. \& J. E. KITCHELL. 1993. The trophic cascade in lakes. Cambridge University Press, New York, USA.

CROSSETTI, L. O., V. BECKER, L. S. CARDOSO, L. R. RODRIGUES, L. S. COSTA \& D. MOTTAMARQUES. 2013. Is phytoplankton functional classification a suitable tool to investigate spatial heterogeneity in a subtropical shallow lake? Limnologica (Jena), 43: 157-163.

FARJALLA, V. F., A. M. AMADO, T. LAQUÊ, B. M. FARIA \& F. A. ESTEVES. 2004. O estado da arte e perspectivas do estudo das bactérias planctônicas nas lagoas da Restinga de Jurubatiba. In: Pesquisas de Longa duração na Restinga de Jurubatiba: Ecologia, História Natural e Conservação. C. F. D Rocha, F. A. Esteves, F. R. Scarano (Eds): 255-272. Rima, São Paulo, Brazil.

FINKLER-FERREIRA, T., E. VAN NES \& D. MOTTA-MARQUES. 2008. Continuous growth of the 
giant grass Zizaniopsis bonariensis in subtropical wetlands. Freshwater Biology, 54: 321-330.

FINKLER-FERREIRA, T. 2009. O papel das macrófitas aquáticas submersas para a dinâmica de lagos rasos subtropicais. $\mathrm{PhD}$ Thesis, Universidade Federal do Rio Grande do Sul, Brazil.

FRAGOSO JÚNIOR, C. R., D. M. L. MOTTA-MARQUES, W. COLLISCHONN, C. E. M. TUCCI \& E. H. VAN NES. 2008. Modelling spatial heterogeneity of phytoplankton in Lake Mangueira, a large shallow subtropical lake in South Brazil. Ecological modelling, 219: 125-137.

GRENOUILLET, G., D. PONT \& K. L. SEIP. 2002. Abundance and species richness as a function of food resources and vegetation structure: juvenile fish assemblages in rivers. Ecography, 25: 641650.

HAMMER, Ø., D. A. T. HARPER \& P. D. RYAN. 2001. PAST: Paleontological Statistics Software Package for Education and Data Analysis. Palaeontologia Electronica, 4: 1-9.

HARRISON, S. \& A. HILDREW. 2001. The role of habitat heterogeneity for epilithic communities in a lake littoral. Journal of Animal Ecology, 70: 692707.

HENNEMANN, M. C. \& M. M. PETRUCIO. 2011. Spatial and temporal dynamic of trophic relevant parameters in a subtropical coastal lagoon in Brazil. Environmental Monitoring and Assessment, 181(1-4): 347-361.

JESPERSEN, A. M. \& K. CHRISTOFFERSEN. 1987. Measurements of chlorophyll-a from phytoplankton using ethanol as extraction solvent. Archive für Hydrobiologie, 109(3): 445-454.

JEPPESEN, E., T. L. LAURIDSEN, T. KAIRESALO \& M. PERROW. 1997. Impact of submerged macrophytes on fish-zooplankton interactions in lakes. In: The structuring role of submerged macrophytes in lakes. E. Jeppesen, M. Søndergaard, M. Søndergaard \& K. Christoffersen (eds): 91114. Springer Verlag, New York, USA.

KOTTEK, M., J. GRIESER, C. BECK, B. RUDOLF \& F. RUBEL. 2006. World Map of the KöppenGeiger climate classification updated. Meteorologische Zeitschrift, 15: 259-263.

LAZZARO, X. 1997. Do the trophic cascade hypothesis and classical biomanipulation approaches apply to tropical lakes/reservoirs? Verhandlungen des Internationalen Verein Limnologie, 26: 719-730.
LOWE-McCONNEL, R. H. 1987. Ecological studies in tropical fish communities. Cambridge University Press, New York, USA.

MACKERETH, F. J. H., J. HERON \& J. F. TALLING. 1989. Water analysis: some revised methods for limnologists. Freshwater Biological Association, Ambleside, UK.

McCUNE, B. \& M. J. MEFFORD. 1999. PC-ORD: multivariate analysis of ecological data, Version 4.10. MjM Software Design, Oregon, USA.

MEERHOFF, M., C. IGLESIAS, F. TEIXEIRA-DEMELLO, J. M. CLEMENTE, E. JENSEN, L. LAURIDSEN \& E. JEPPESEN. 2007. Effects of habitat complexity on community structure and predator avoidance behaviour of littoral zooplankton in temperate versus subtropical shallow lakes. Freshwater Biology, 52: 1009-1021.

MEHNER, T., F. HOLKER \& P. KASPRZAK. 2005. Spatial and temporal heterogeneity of trophic variables in a deep lake as reflected by repeated singular samplings. Oikos, 108: 401-409.

MOSS, B. 1990. Engineering and biological approaches to the restoration from eutrophication of shallow lakes in which aquatic plant communities are important components. Hydrobiologia, 200/201: 367-377.

PINEL-ALLOUL, B., C. GUAY, N. ANGELI, P. LEGENDRE, P. DUTILLEUL, G. BALVAY, D. GERDEAUX \& J. GUILLARD. 1999. Large-scale spatial heterogeneity of macrozooplankton in Lake of Geneva. Canadian Journal of Fisheries and Aquatic Sciences, 56: 1437-1451.

REYNOLDS, C. S. 2006. The Ecology of Phytoplankton: Ecology, Biodiversity and Conservation. Cambridge University Press, New York, USA.

RODRIGUES, L. R., N. F. FONTOURA \& D. MOTTA-MARQUES. 2014. Food-web structure in a subtropical coastal lake: how phylogenetic constraints may affect species linkages. Marine and Freshwater Research, 65: 453-465.

RODRIGUEZ, M. A. \& W. M. LEWIS. 1997. Structure of fish assemblages along environmental gradients in floodplain lakes of the Orinoco River. Ecological Monographs, 67: 109-128.

SÁNCHEZ-BOTERO, J. I., E. P. CARAMASCHI \& D. S. GARCEZ. 2008. Spatio-temporal variation in fish assemblage in a coastal lagoon without direct contact with the sea (southeastern Brazil). Journal of Coastal Research, 24: 181-194. 
TEIXEIRA-DE-MELLO, F., M. MEERHOFF, Z. PEKCAN-HEKIM \& E. JEPPESEN. 2009. Substantial differences in littoral fish community structure and dynamics in subtropical and temperate shallow lakes. Freshwater Biology, 54: 1202-1215.

TEJERINA-GARRO, F. L., R. FORTIN \& M. A. RODRIGUEZ. 1998. Fish community structure in relation to environmental variation in floodplain lakes of the Araguaia River, Amazon Basin. Environmental Biology of Fishes, 51: 399-410.

THACKERAY, S. J., D. G. GEORGE, R. J. JONES \& I. J. WINFIELD. 2004. Quantitative analysis of the importance of wind-induced circulation for the spatial structuring of planktonic populations. Freshwater Biology, 49: 1091-1102.

TOMAZELLI, L. J., S. R. DILLENBURG \& J. A. VILLWOCK. 2000. Late Quaternary geological history of Rio Grande do Sul coastal plain, southern Brazil. Revista Brasileira de Geociências, 30:
474-476.

VANDER ZANDEN, M. J. \& Y. VADEBONCOEUR. 2002. Fishes as integrators of benthic and pelagic food webs in lakes. Ecology, 83: 2152-2161.

WERSAL, R. M., J. D. MADSEN, B. R. MCMILLAN \& P. D. GERARD. 2006. Environmental factors affecting biomass and distribution of Stuckenia pectinata in the heron lake system, Minnesota, USA. Wetlands, 26(2): 313-321.

WETZEL, R. G. 1992. Gradient-dominated ecosystems: Sources and regulatory functions of dissolved organic matter in freshwater ecosystems. Hydrobiologia, 229: 181-198.

WOODWARD, G. \& A. G. HILDREW. 2002. Food web structure in riverine landscapes. Freshwater Biology, 47: 777-798.

ZERBA, K. E. \& J. P. COLLINS. 1992. Spatial heterogeneity and individual variation in diet of on aquatic top predator. Ecology, 73: 268-279. 